\title{
Filsafat Crowdsourcing : Instan dan Universal
}

\author{
Soetam Rizky Wicaksono ${ }^{{ }^{*}}$ \\ ${ }^{1}$ Pusat Pengembangan TI Terapan Universitas Ma Chung \\ *Email: soetam.rizky@machung.ac.id
}

\begin{abstract}
Perkembangan teknologi di bidang sistem informasi yang semakin pesat membawa sebuah generasi baru yang dinamakan net generation. Generasi baru tersebut yang secara myata telah terasuki candu web, khususnya yang mengaplikasikan model social networking, pada akhirnya menciptakan sebuah fenomena baru yang menjadikan sebuah filsafat bersifat universal dan instan. Fenomena tersebut bisa disebut sebagai sebuah filsafat model crowdsourcing, yang di dalam makalah ini berusaha dibahas dari sudut pandang kajian pustaka yang menjadi dasar dari eksperimen untuk penerapan pembelajaran dengan basis crowdsourcing.
\end{abstract}

Keywords: Crowdsourcing, Filsafat Instan, Universal 


\section{Pendahuluan}

Tak bisa dipungkiri bahwa fenomena perkembangan teknologi informasi saat ini sangat berpengaruh terhadap perkembangan keilmuan secara global. Secara otomatis, hal tersebut juga dapat dipastikan berpengaruh kepada bidang ilmu filsafat yang dipastikan dengan adanya perkembangan teknologi akan dapat menembus batasan ruang dan waktu.

Generasi yang ada saat ini, dijuluki sebagai net generation yang didefunisikan sebagai generasi yang lahir setelah tahun 1980-an dan sesungguhnya lebih cerdas namun menginginkan hasil yang lebih cepat atau secara instan (Beyers 2009; Jones \& Healing 2010; Waters 2012).Tentu saja hal tersebut juga berpengaruh terhadap perkembangan filosofi yang ada di masa kini, saat sebuah filsafat tidak hanya lagi bersifat personal, tetapi juga tidak bisa lagi dibatasi dalam satu area negara atau nasional, tetapi lebih bersifat global dan universal.

Filosofi yang dimiliki secara personal bukanlah sesuatu hal yang "tidak penting" secara pragmatis, sebab kepemilikan seseorang terhadap filosofi personal telah terbukti secara empiris dapat meningkatkan produktifitas orang tersebut di dalam raihan hidup serta pekerjaan yang dijalani (Stilman 2010). Ini membuktikan bahwa seseorang memang seharusnya memiliki filosofi personal di tiap dirinya masing-masing.

Dengan kaitan bahwa filosofi personal adalah hal yang penting dimiliki oleh tiap orang di dalam raihan hidup serta perjalanan hidup yang harus dijalani, sedangkan di sisi lain filosofi yang bersifat personal telah bermetamorfosa menjadi sebuah filosofi yang dalam sekejap mata berubah menjadi filosofi global. Maka tak pelak lagi, filosofi yang saat ini berkembang di lingkungan net generation adalah sebuah filosofi yang terbentuk dari model crowdsourcing, yakni sebuah model yang pengetahuan didalamnya terbentuk dari berbagai jenis dan tipe orang yang secara sengaja maupun tidak sengaja berkumpul di sebuah lingkungan sosial berbasis online (Borst 2010).

Model crowdsourcing yang secara instan dapat menghasilkan sebuah panduan filosofi baru juga sekaligus secara langsung dapat mengubah filosofi personal seseorang jika di dalam sebuah lingkup sosial terdapat seseorang yang menjadi panutan dan dianggap superior di dalam pengungkapan filsafah kehidupan. Superioritas panutan tersebut pada akhirnya dapat melahirkan sebuah ideologi baru yang tidak lagi terbatas dengan kondisi ruang dan waktu, tetapi seketika akan berlaku secara global (Freeden 2003).

Hal tersebut berarti bahwa model crowdsourcing di dalam lingkungan sosial berbasis online telah menafikan anggota komunitasnya dari perbedaan ras, agama, etnis, kewarganegaraan ataupun perbedaan lainnya yang sering menjadi batasan dalam anutan filosofi seseorang. Sebagai contoh, filosofi mengenai penafian Tuhan yang berkembang menjadi ideologi komunis kini tidak hanya berkembang di sebuah-negara komunis seperti Kuba atau Korea Utara, tetapi dengan munculnya beragam situs online yang menawarkan filosofi keduniaan sebagai penghambaan utama maka secara tidak sadar para partisipan di dalam situs tersebut bisa jadi akan memiliki kesepahaman yang sama mengenai komunisme yang juga sekaligus menjadikan filsafah hidup secara personal yang mereka anut juga menjadi berubah arah.

Dari uraian tersebut, maka makalah ini berusaha membahas mengenai fenomena perubahan pembentukan filosofi instan yang terjadi pada dekade kedua di abad 21, yakni pada saat net generation telah dikuasai oleh teknologi berbasis online yang menyebabkan terbentuknya sebuah lingkungan sosial berbasis 
global (Waters 2012), dan akibatnya menjadikan filosofi yang sebelumnya bersifat personal dan akhirnya berkembang pesat secara instan menjadi bersifat universal dengan bantuan model crowdsourcing didalamnya.

\section{Kajian Pustaka}

Filsafat yang bisa didefinisikan sebagai usaha untuk mencari kebijaksanaan dalam hidup (Syam 2006), bisa menjadi sebuah perenungan yang didalamnya akan membawa manusia ke dalam sebuah hakikat pemaknaan hidup. Upaya manusia dalam berfilsafat sesungguhnya terdorong oleh perasaan bahwa seseorang seharusnya mengetahui dengan pasti bahwa dirinya tidak mengetahui tentang apapun (the one thing I know is that I know nothing), sehingga didalamnya terbersit keinginan untuk mencari tahu mengenai makna hidup (Pessin 2009).

Filsafat yang dianut seseorang dipastikan akan berbeda satu sama lain, meski ideologi yang dianut kerap sama. Karena secara personal, filsafat hidup bisa bergantung kepada pengalaman yang telah dilalui serta cara menghadapi krisis yang dilalui dalam hidup. Keberadaan filsafat secara personal atau lazim disebut sebagai eksistensialisme tersebut juga dipengaruhi oleh lingkungan sosial yang dihadapi oleh tiap orang di dalam perjalanan hidupnya (Flynn 2006).

Dalam perjalanan hidup manusia, secara personal manusia akan terpengaruh dengan filsafat yang dia miliki baik dari sisi pekerjaan ataupun pengetahuan yang diperoleh (Stilman 2010). Selain itu, filsafat secara personal juga akan mempengaruhi perilaku manusia sebagai mahluk bermoral, seperti halnya pendapat David Hume dalam teori science of man yang mengasumsikan bahwa sumber pengetahuan adalah pengalaman sehingga moral manusia dapat dipengaruhi oleh penerapan ilmu (Abqary 2009).

Perjalanan hidup seorang manusia, meski telah disebutkan akan mempengaruhi filsafat hidup yang ia miliki dan ia anut, tidak akan sepenuhnya menjadikan seorang manusia menjadi tertutup terhadap filsafat yang berkembang di dunia luar selain dunia yang ia jalani saat ini. Hal ini dikarenakan bahwa manusia modern yang hidup pada saat ini dinyatakan memiliki ciri keterbukaan "aku" sebagai sebuah mahluk sosial yang memiliki tugas, kebebasan serta tanggung jawab terhadap dunia, sesama manusia serta Tuhan (Leenhouwers 1988).

Hal tersebut berarti menyatakan bahwa filsafat personal seseorang dapat secara pelan-pelan ataupun drastis berubah sesuai dengan lingkungan yang ia tempati. Perubahan tersebut bisa juga tidak terjadi, sebab kodrat manusia adalah sebagai mahluk yang memiliki kemampuan untuk berkehendak dan memilih di dalam perjalanan hidupnya (Leahy 1989). Tetapi di satu sisi, bahwa tindakan yang dilakukan seseorang dipastikan merupakan manifestasi dari filsafat hidup yang ia miliki, mengingat bahwa filosofi lebih berfokus kepada cara yang tepat untuk bertindak dibandingkan sebuah kumpulan abstrak dari kebenaran teori (Flynn 2006).

Jika ditarik lebih lanjut, dari kumpulan filsafat secara personal dan terbuka bagi publik yang kemudian dimiliki oleh para penguasa sebuah negara atau pemerintahan, maka secara otomatis filsafat tersebut akan bersifat nasional dan menjadi sebuah ideologi yang dianut dalam sebuah negara (Freeden 2003). Filsafat negara yang selanjutnya menjadi sebuah dasar negara menjadi sebuah sistem yang filsafat dan ideologi yang melembaga yakni dalam wujud sistem kenegaraan sehingga mampu memandu tatanan kebangsaan suatu negara (Syam 2006). 


\section{An Anthology VI, July 2013}

Penembusan batas ruang dan waktu oleh berbagai jenis jejaring sosial yang semakin meledak penggunaannya saat ini, menjadikan fenomena internet yang mengutamakan aktifitas dan interaksi sosial dibanding personal atau lazim disebut sebagai Web 2.0 menjadi sebuah manifestasi filsafat net generation saat ini (Jones 2008). Fenomena sosiologis Web 2.0 yang membentuk sebuah komunitas yang bisa secara sengaja atau tidak sengaja menetapkan sebuah tujuan yang sama dan umumnya bersifat temporer, telah membentuk sebuah model baru dalam pencarian sumber belajar yang dinamakan crowdsourcing (Borst 2010; Beyers 2009; Jones \& Healing 2010).

Crowd yang dapat diartikan sebagai kumpulan manusia jika dipandang dari sisi sosiologis dibagi menjadi empat jenis yakni (Blumer. 1972) : casual crowd (jika kumpulan tersebut terbentuk dan kemudian bubar secara normal, misal: kumpulan orang di sebuah taman), conventionalized crowd ( jika kumpulan tersebut terbentuk akibat adanya tujuan yang sama dan bertindak dalam sebuah keseragaman, misal: penonton yang secara otomatis samasama memberi dukungan dalam sebuah pertandingan olahraga), acting crowd (kumpulan manusia yang secara tidak sengaja terbentuk akibat ketertarikan terhadap sesuatu, misal: sekumpulan orang yang melihat sebuah kecelakaan di jalan) dan yang terakhir adalah expressive crowd (kumpulan manusia yang tidak memiliki tujuan sama namun memiliki emosi yang sama dalam suatu waktu, misal: saat seorang pencopet tertangkap, maka akan dipukuli secara beramai-ramai, meski beberapa orang hanya memukul karena meluapkan emosi terhadap hal lain di dalam kehidupannya).

Dalam konteks ini, komunitas yang terbentuk secara online dan menerapkan model crowdsourcing didalamnya bisa jadi tergolong ke dalam expressive crowd pada saat awal, namun di perkembangan selanjutnya dapat secara cepat berubah menjadi

\section{Teknologi Pembelajaran dan Terapan}

conventionalized crowd atau acting crowd. Perilaku yang terjadi dalam komunitas dan ditindaklanjuti secara kolektif secara alamiah akan merasuk ke dalam individu yang ada didalamnya dan menjadi sebuah arah kehidupan yang baru atau new order of life (Blumer 1972).

Crowdsourcing yang menempatkan berbagai sumber ilmu di dalam sebuah wahana baru secara online dan seringkali diwarnai ketidaksahihan sumber tersebut malah menjadikan para anggota komunitas didalamnya menjadikan hasil kumpulan sumber ilmu tersebut menjadi sesuatu yang "sangat benar" (Borst 2010). Hal ini disebabkan kodrat manusia yang disebut sebagai mahluk terbuka secara horizontal yang menjadikan manusia menganggap dirinya sebagai bagian dari sebuah kumpulan spesies yang turut mengambil bagian dalam kodrat manusia yang sama dengan manusia yang lain (Leenhouwers 1988).

Ini berarti bahwa keuniversalan sebuah filsafat saat ini, terutama di kalangan net generation, seringkali dipengaruhi dari efek perjalanan online seseorang. Sebagai contoh radikal, pencarian mengenai filsafat hidup seorang teroris bisa jadi terjadi karena yang bersangkutan terlalu sering melakukan perjalanan online (browsing) dan menjadi partisipan aktif dalam berbagai situs yang bersifat ekstrim terhadap kehidupan beragama ataupun ketidaksetujuan terhadap falsafah negara yang ia tempati (Jones 2008).

Dengan melihat fenomena yang saat ini terjadi dalam keuniversalan filsafat saat ini yang menjadi pengejawantahan dari keterbukaan filsafat personal maka tidak bisa dipungkiri bahwa perkembangan teknologi di bidang sistem informasi saat ini telah mengubah paradigma pemerolehan filsafat hidup seseorang. Dan dengan adanya globalisasi Web 2.0 yang semakin merasuk ke net generation, maka filsafat secara universal telah menjadi sebuah 
pergumulan dan kontemplasi instan dari sebuah komunitas yang menerapkan model crowdsourcing didalamnya.

\section{Pembahasan}

Filsafat hidup seseorang yang pada masa lalu dianggap sangat personal dari sisi eksistensialisme, dan bahkan seringkali dianggap sebagai sesuatu yang mungkin tidak perlu diketahui oleh orang lain, saat ini telah (Flynn 2006), berubah posisi. Tren Web 2.0 yang menjadikan para partisipan aktif didalamnya menjadi seorang freak mind blogging (Jones 2008) malah mengubah paradigma bahwa filsafat hidup seseorang seharusnya disebarluaskan serta jika bisa harus ditanggapi atau bahkan dianut oleh sekumpulan partisipan aktif lainnya.

Keberadaan situs jejaring sosial yang semakin menguat dari waktu ke waktu dan merasuk ke dalam kehidupan para manusia di lingkup net generation, tanpa disadari telah membuat sebuah aliran filsafat yang diperbarui di dalam kehidupan manusia. Kemungkinan juga bahwa sesungguhnya aliran filsafat tersebut hanyalah pengejawantahan model baru dari aliran yang sudah ada. Sebagai sumber pencarian keilmuan, filsafat yang muncul di dalam lingkup tren Web 2.0 dan terbentuk akibat adanya model crowdsourcing bisa digolongkan ke dalam sebuah metode pencarian keilmuan yang menggabungkan antara rasionalisme dan empirisme.

Hal tersebut didasari oleh adanya aliran rasionalisme yang mengandalkan ide yang abstrak dan digabungkan dengan aliran empirisme yang memprioritaskan pengalaman sebagai sumber pengetahuan (Hooner \& Hunt 1978). Gabungan dari kedua aliran tersebut implementasinya tersurat pada model crowdsourcing yang terjadi saat ini, yakni pada saat rasionalisme seseorang yang secara abstrak diungkapkan ke dalam sebuah situs (baik berupa situs blog, jurnal pribadi, semi komersial ataupun jejaring sosial), dianggap sebagai sebuah bukti empiris oleh para partisipan aktif didalamnya.

Sebagai contoh, jika pada sebuah situs jejaring sosial yang berupa forum, terdapat seseorang yang berasal dari Indonesia berusaha mengungkapkan filsafat pribadinya yang dipengaruhi oleh filsafat negara yakni mengenai Kemanusiaan Yang Adil dan Beradab, selanjutnya ditanggapi secara antusias oleh partisipan lain yang berasal dari negara Kuba yang dalam perjalanan hidupnya sangat dipengaruhi oleh ajaran komunis. Maka yang terjadi bahwa partisipan asal Kuba akan mengasumsikan kata Adil sebagai sebuah azas sama rata sama rasa dan secara positif menanggapi mengenai butir filsafat tersebut.Tetapi di satu sisi, seorang partisipan aktif yang berasal dari Amerika Serikat dan memahami filsafat Pancasila serta membenci negara Kuba akan secara negatif menentang tanggapan tersebut.

Dari perdebatan kecil tersebut, pada akhirnya muncul sebuah filsafat baru yang menetapkan bahwa kata Adil lebih mengarah ke justice bukan equal. Tentu saja hal tersebut terbentuk dari model crowdsourcing yang bisa dikatakan sebagai sebuah kontribusi dari berbagai partisipan aktif yang ada dalam situs tersebut yang sekaligus juga secara tidak sadar memberikan pengaruh terhadap partisipan lain yang secara pasif mengikuti diskusi tersebut. Hasil dari diskusi yang secara riil para pesertanya tidak pernah bertatap muka secara langsung, tidak mengenal secara personal dan bahkan tidak mengetahui nama asli dari para partisipan tersebut, malah dapat menjadikan seorang partisipan (aktif ataupun pasif) memiliki filsafat hidup personal yang baru di dalam kehidupannya.

Dari contoh sekilas tersebut dapat dikatakan bahwa filsafat yang muncul dari implementasi model crowdsourcing yang saat ini 
berkembang berdasarkan tren Web 2.0, menjadikan filsafat personal yang sebelumnya hanya dimiliki oleh seseorang dan dipengaruhi oleh filsafat nasional dari negara yang ia tempati dapat secara cepat dan tepat menyebar ke berbagai belahan dunia lain dan menjadi sebuah filsafat yang bersifat universal.

Contoh lain adalah tulisan bersifat pribadi yang mengungkapkan filsafat hidup seseorang di dalam sebuah situs pribadi atau blog, bisa jadi secara tidak sadar akan mempengaruhi orang lain yang menganggap bahwa sang penulis lebih superior dibandingkan dirinya sendiri. Situs para motivator yang mengungkapkan filsafat hidup yang mungkin sebelumnya tidak pernah terpikir oleh para partisipan secara mendadak menjadi sebuah acuan hidup yang seringkali telah terbersit sebelumnya di bidang religi. Contoh nyata dari kasus ini seperti tulisan yang dibuat para motivator seperti Mario Teguh, Andre Wongso atau Kafi Kurnia yang seringkali menjadi sebuah filsafat personal bagi para simpatisannya. Contoh lainnya adalah tulisan seorang dosen yang mengungkapkan filsafat hidupnya di blog, dan secara tidak sadar mempengaruhi filsafat hidup para mahasiswa aktif yang mengikuti kelas dosen tersebut.

Sebagai sebuah filsafat universal yang terbentuk dari hasil model crowdsourcing, maka tidaklah mungkin hasil tersebut diklaim menjadi sebuah filsafat yang diciptakan oleh seseorang saja. Tidak ada lagi teori filsafat baru yang diasumsikan dengan seseorang seperti layaknya filsafat di masa lampau, sebagai contoh filsafat dari Plato, filsafat dari Descartes atau filsafat dari Locke. Tetapi saat ini yang mungkin muncul dari hasil filsafat crowdsourcing tersebut adalah filsafat dari blog si X, filsafat dari forum Kaskus atau filsafat yang muncul dari grup di lingkup Facebook.
Tetapi di sisi lain, kebebasan mengungkapkan filsafat dari pendapat pribadi juga bisa menjadi bumerang bagi kehidupan sosial bermasyarakat di sebuah negara. Seperti yang telah dijabarkan sebelumnya di bab kajian pustaka, bahwa filsafat hidup personal bisa dengan cepat berubah dan berevolusi menjadi radikal pada saat seseorang secara sengaja atau tidak menjadi partisipan di sebuah situs yang "sesat" dalam berfilsafat.

Kelemahan lain yang timbul akibat implementasi filsafat crowdsourcing ini adalah semakin menguatnya ciri net generation yang sesungguhnya dianggap lebih cerdas dibandingkan generasi sebelumnya, tetapi selalu mengharapkan hasil yang serba instan dan cepat (Beyers 2009). Dengan adanya filsafat crowdsourcing, maka situs mesin pencari seperti Google, Yahoo ataupun Bing menjadi "dewa" baru dalam pencarian filsafat hidup. Meski secara empiris, para partisipan sesungguhnya tidak mengalami secara langsung pengalaman hidup yang seharusnya menjadi sumber dari pencarian keilmuan, tetapi dengan adanya berbagai situs video streaming seperti YouTube, menjadikan para partisipannya seakan-akan telah mengalami pengalaman tersebut secara virtual.

Dari sebuah filsafat personal yang berbasis pengalaman hidup secara empiris dari seseorang yang kemudian menguat menjadi sebuah filsafat bersifat nasional akibat adanya kesamaan lingkungan tempat hidup, maka saat ini filsafat yang secara universal dianut banyak orang dengan menisbikan batas ruang dan waktu, secara cepat tercipta berkat adanya kemajuan teknologi di bidang sistem informasi. Mengacu kepada kelebihan yang bisa menjadikan seseorang dapat berfilsafat secara instan di dunia virtual, maka filsafat crowdsourcing tidak lagi menjadi sebuah tren di masa kini, tetapi secara nyata dapat membantu para net generation mencari pemaknaan hidup tanpa harus melampaui proses kontemplasi yang panjang dan berliku. 
Namun dengan melihat kelemahan yang ada di dalam proses berfilsafat seara crowdsourcing, maka seperti halnya sebuah pisau bermata dua, para partisipan yang masih tergolong sebagai net generation memang diharapkan lebih waspada terhadap pengungkapan filsafat oleh seseorang. Selain itu juga wajib diwaspadai asal dari sumber filsafat tersebut, sebelum para partisipan atau simpatisannya menjadikan filsafat tersebut sebagai ideologi yang dianut agar tidak terjerumus ke jalan pemikiran yang dianggap salah.

\section{Kesimpulan}

Dari uraian yang telah dihasilkan tersebut, dapat ditarik beberapa kesimpulan yakni perkembangan teknologi di bidang sistem informasi. telah menerbitkan sebuah tren Web 2.0 yang tidak hanya bisa ditinjau dari perkembangan secara teknis, tetapi lebih dilihat dari fenomena crowdsourcing yang muncul dari hasil perilaku freak mind blogging yang merasuki sebagian besar golongan net generation.

Model crowdsourcing yang muncul dari tren Web 2.0 memunculkan keberadaan filsafat crowdsourcing yang secara instan dihasilkan dari pemikiran berbagai orang lintas budaya dan lintas negara yang terlibat sebagai partisipan di dalam komunitas berbasis online sehingga menembus batas ruang dan waktu untuk mengubah sebuah filsafat personal bermetamorfosa menjadi filsafat yang bersifat universal.

Keberadaan filsafat crowdsourcing layaknya sebuah pisau bermata dua yang memiliki keunggulan sekaligus kelemahan didalamnya. Keunggulan dari filsafat ini yang menjadikan net generation menjalani kontemplasi instan serta memunculkan filsafat personal ke arah yang lebih baik dibarengi dengan kelemahan dari filsafat crowdsourcing yang juga dapat secara radikal merevolusi jalan pikiran seseorang menjadi ekstrem dan tidak lagi sesuai dengan ajaran agama ataupun menentang budaya lokal.

Manusia sebagai mahluk sosial yang tidak hanya menjadi mahluk individu, secara naluriah merasakan dirinya sebagai bagian dari sebuah komunitas (dengan menganut filsafat hidup dari filsafat crowdsourcing atau mengkombinasikannya dengan pengalaman hidup), sekaligus secara alamiah ingin diakui keberadaannya dengan mengungkapkan filsafah personal yang ia miliki ke berbagai situs dan menjadi partisipan aktif dalam pembentıkan filsafat crowdsourcing.

\section{Kepustakaan}

Abqary, Q, 2009, Melawan Fasisme Ilmu, Penerbit Kelindan, Jakarta.

Beyers, RN, 2009, 'A Five Dimensional Model for Educating the Net Generation', Educational Technology \& Society, vol 12 , no. 4, p. 218-227.

Blumer, H, 1972, 'Forms of Crowd and Mass Behaviour', in $\mathrm{HH}$ MacGill (ed.), Crowd and Mass Behaviour, American Sociological Association.

Borst, I, 2010, 'Understanding Crowdsourcing', ERIM PhD Series in Research in Management, Erasmus Universiteit Rotterdam, Rotterdam.

Flynn, T, 2006, Existensialism, a very short introduction, Oxford University Press, Oxford.

Freeden, M, 2003, Ideology, a very short introduction, Oxford University Press, Oxford. 
Hooner, SM \& Hunt, TC, 1978, 'Metode dalam Mencari Pengetahuan: Rasionalisme, Empirisme dan Metode Keilmuan', in JS Suriasumantri (ed.), Ilmu Dalam Perspektif, Penerbit Gramedia, Jakarta.

Jones, BL, 2008, Web 2.0 Heroes: Interviews with 20 Web 2.0 Influencers, Wiley Publishing.

Jones, C \& Healing, G, 2010, 'Net generation students: agency and choice and the new technologies', Journal of Computer Assisted Learning, vol 26, pp. 344-356.

Leahy, L, 1989, Manusia, Sebuah Misteri, Penerbit Gramedia, Jakarta.

Leenhouwers, P, 1988, Manusia dalam Lingkungannya (terjemahan oleh K.J. Veeger M.A), Penerbit Gramedia, . Jakarta.

Pessin, A, 2009, The 60-second Philosopher - Expand your mind on a minute or so a day, One Word, Oxford.

Stilman, TF, 2010, 'Personal Philosophy and Personnel Achievement: Belief in Free Will Predicts Better Job Performance', Social Psychological and Personality Science, vol 1, no. 1, pp. 43-50.

Syam, MN, 2006, Filsafat Ilmu, FIP Universitas Negeri Malang, Malang.

Waters, JK, 2012, 'John Q. Netizen', Campus Technology, March 2012, pp. 19-22.

\section{PEMANFAATAN FITUR CITATIONS DAN BIBLIOGRAPHY DALAM MICROSOFT OFFICE UNTUK PENULISAN KARYA ILMIAH}

\author{
Oesman Hendra Kelana \\ Faculty of Sains and Technology, University of Ma Chung, \\ Malang \\ E-mail : oesman.hendra@machung.ac.id
}

\section{ABSTRACT}

In academic world, every word and idea must be apreciated and make citation that refer to the author. But sometimes the academic writers do not write the citations accurately. Usually they make citation on the text, but inadvertent do not write the reference resources in bibliography. This article discuss how to use the feature from Microsoft Word to create accurate citation and bibliography so the inaccuracy can be avoided. With this feature, the writers can also adjust the citation style according to the requirement.

Key Words : Reference, Citation, Bibliography, Citation Style. 